with the students. One reason is that the assignment taps a deep reservoir of uncertainty among students who tend to favor the status quo. In all likelihood, the students will search for the hidden rules of the game in the first few weeks, so it may be important to provide significant latitude and encouragement in developing their papers. Within several weeks, though, the students will become increasingly confident in their own abilities and increasingly fascinated by exploring ideas and the individuals who developed them.

\section{References}

DuBois, W.E.B. 1989. The Souls of Black Folk. New York: Bantam.

James, Henry. 1968. The American Scene. Bloomington: Indiana University Press. Safire, William. 1987. Freedom. Garden City, NY: Doubleday.

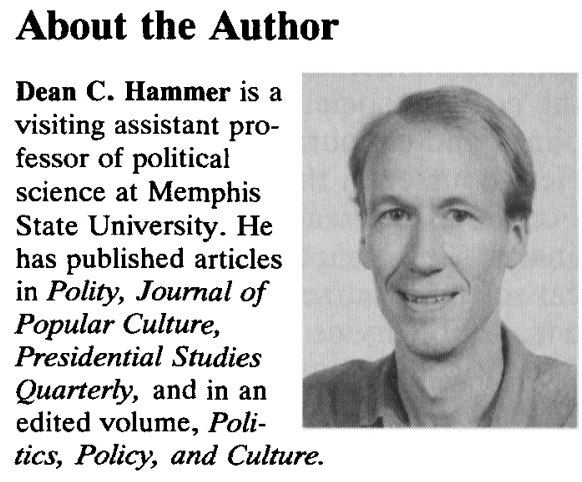

\title{
APSA Guidelines for Teacher Training: Recommendations for Certifying Precollegiate Teachers of Civics, Government, and Social Studies*
}

\section{Objectives}

When the American Political Science Association held its second annual meeting in 1905, a major presentation was "What Do Entering College Freshmen Know About American Government Before Taking College Courses in Political Science?" From that time on, the Association has maintained standing committees and projects devoted to precollegiate education in civics, government, and politics. This is as it should be: citizenship education is a primary objective of American schooling, and political science is the core subject of civic literacy and competence.

The increasing concern over the competence of teachers and the preparation of students to participate fully and knowledgeably in American society now prompts the APSA to respond to requests for its recommendations regarding the certification of teachers of government, politics, social studies, and civics in secondary schools. The recognition that education must provide the foundation for students' academic skills and civic competency should also be addressed by recommendations as to the preparation of the elementary and secondary teachers who first introduce the study of American values and institutions.

\section{Audiences: Who May Use These Guidelines}

The guidelines have been prepared by the Association's Education Committee in consultation with many other faculty in political science and colleges of education. The guidelines are for reference and use by the following organizations responsible for designing curricula and training and certifying teachers:

- Colleges and universities with programs that certify elementary, middle and high school social studies, civics and government teachers

- State education agencies that establish standards for certifying or licensing social studies, civics and government teachers

- Agencies that evaluate and accredit teacher education programs

- Professional organizations for precollege teachers, particularly the National Council for the Social Studies, and the regional and state councils for the social studies

- Organizations that are examining and proposing reforms in precollegiate education

- Political science departments in colleges and universities who are responsible, wholly or in part, for providing the courses to be taken by teachers seeking certification in social studies, civics, and government

The Certification of Secondary School Teachers of Civics and Government

\section{Political Science}

Teachers of civics and government in particular, and also of social studies, are advised to pursue a major in political science. The undergraduate political science major shares the objective of precollege civics and social studies instruction, namely ". . . [T]o maximize students' capacity to analyze and interpret the significance and dynamics of political events and governmental processes ... [t]o equip them for coping with political events and governmental actions and problems in the future. 'Coping with' in this context means not merely to understand, or to manage their effects on society and on them individually, but also to evaluate and seek to shape them.",

The political science major includes courses on democratic theory, constitutional democracy, and political institutions and processes that are the core of precollege instruction in civics and government. Moreover, the subjects and skills of a political science major are compatible with a broader social sci- 
ences/social studies perspective. As a discipline, political science encompasses methods of inquiry of the cognate social science disciplines and encourages its majors to elect courses in these disciplines. For the future teacher, historical analysis is a valuable tool for political science courses and for a minor. A preservice teacher majoring in political science who minors in history should be qualified to teach history as well as civics and government.

Political science students study American government as well as comparative, multicultural, and international perspectives on political life. Their training emphasizes mastery of written and oral communications skills and analytical skills that precollege teachers of civics and social studies recognize as fundamental to their instructional objectives.

While a major is recommended, the prospective teacher should have at least a minor in political science, but a major or the following equivalent credit hours in political science is preferable. The distribution of courses should include Introductory American Government, assure exposure to major subfields in political science, and provide some study in depth in American politics and comparative politics through advanced courses.

For teachers of secondary school civics and government courses, notably American government and comparative government, the following courses are recommended.

\section{Primary Courses}

Introduction to American Government and Politics 1-2 semesters Introduction to Comparative Government and Politics

1 semester

International Relations 1 semester Political Theory 1 semester

\section{Recommended Courses}

In selecting these courses, prospective secondary school civics and government teachers are strongly encouraged to gain exposure to (a) the philosophical issues of political democracy and democratic citizenship; (b) the cultural, ethnic, gender, racial, and other sources of pluralism of American political life; and (c) methods of political science data analysis.

Advanced courses in American government and politics and public law, including state and local government

2-3 semesters (for a total of 4 semesters in American government and politics, including the introductory course)

Courses in comparative politics

This should include developing and non-western countries in addition to more familiar Western European nations. 2 semesters

Political Theory/Philosophy 1-2 semesters

\section{Cognate Disciplines}

Many middle and high school teachers of civics and government will be responsible for teaching courses in history, economics, and the other social sciences. To prepare them to do so, selected course work from at least three of the following disciplines is recommended: history, economics, geography, sociology, anthropology, and psychology.

\section{Professional Education/ Teacher Training}

Secondary school civics, government, and social studies teachers should receive training in instructional strategies and practices and in the application of these strate- gies to the presentation of specific subjects in government and politics.

\section{Preparation of Elementary School Teachers}

Citizenship education is an important component of elementary education. Our very youngest students receive their first formal instruction in democratic values, cooperation, and participation in their school and community. Early schooling should introduce young students to the norms of American constitutional order and to the ways in which participation in American democracy has been expanded.

Students in the upper primary grades receive their first instruction in American history and the foundations of American democracy and in their state's history and government. Political science training will give elementary teachers the concepts and context needed to introduce these topics.

Elementary school teachers are advised to take at least two semesters of political science, but four semesters are preferable. At least one semester of American Government and Politics should be required, and courses in comparative government and politics and state and local government are recommended.

\section{Notes}

*These guidelines were developed by successive APSA Education Committees from 1991-93.

For a full description of the objectives and attributes of the political science major, see John C. Wahlke, "Liberal Learning and the Political Science Major,"' PS: Political Science \& Politics, 24 (March 1991), 48-60. (Available from APSA upon request: (202) 483-2512.) 